\title{
Historein
}

Vol 14, No 2 (2014)

Historein 14/2 (2014)

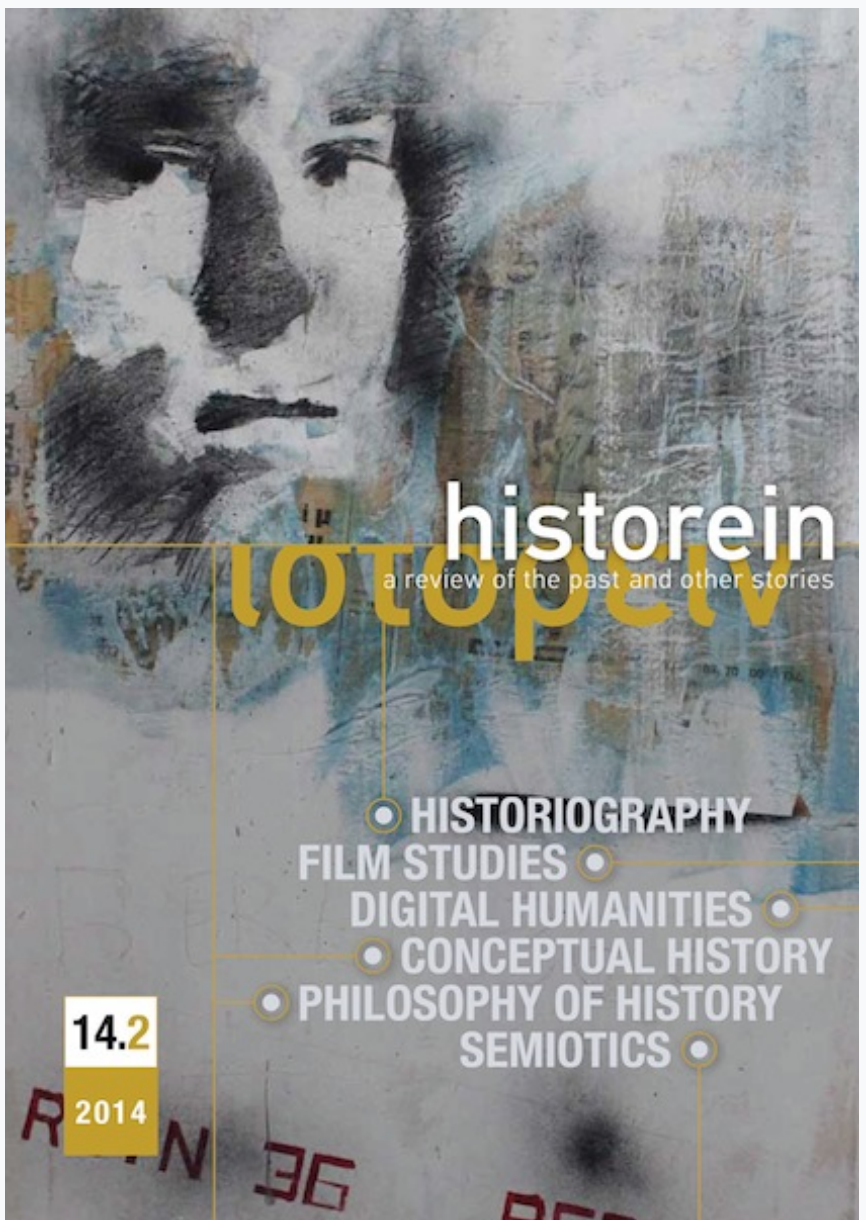

\section{Institutional and conceptual transformations of philosophy of history}

Ivelina Ivanova, Todor Hristov

doi: $10.12681 /$ historein.231

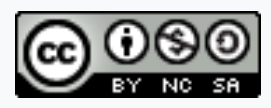

This work is licensed under a Creative Commons Attribution-NonCommercialShareAlike 4.0.

\section{To cite this article:}

Ivanova, I., \& Hristov, T. (2013). Institutional and conceptual transformations of philosophy of history. Historein, 14(2), 18-29. https://doi.org/10.12681/historein.231 


\section{Institutional}

\section{and conceptual \\ transformations \\ of philosophy of \\ history}

The eighteenth and nineteenth centuries witnessed the development of two parallel conceptual strategies that shaped historical thought: first, speculative philosophies of history, and, second, theoretical projects for grounding and developing a science of history (either modelled on the natural sciences or proclaiming the specificity of Geisteswissenschaften).'

These conceptual strategies initiated a crystallisation and reorientation of knowledge about history that enabled the radical transformation of historical thought in the second half of the twentieth century. The transformation was driven by an attentive, sometimes even suspicious, analysis of the uses and the production of historical knowledge, an analysis that made many issues that once seemed self-evident appear difficult and problematic.

In this article we will try to illustrate this transformation by mapping out the marginalisation of classical modes of thinking on history (as for example the grand projects of speculative or universal history) and the waning interest in formerly important research topics (such as the problem of historical laws or the difference between the natural sciences and Geisteswissenschaften), while other topics have retained their salience (for example, interpretation, values or the impact of the present on the representation of the past) and newly emerging topics have gained sudden prominence (narrative, rhetoric, reading, discourse analysis, everyday life etc).

In order to do that, we will sum up the findings of two studies: a content analysis of History and Theory, an academic journal, which played a central part in developments in this research 
area, and an analysis of the institutional localisation and geographic distribution of university courses in philosophy of history.

\section{The content analysis}

History and Theory is one of the foremost English-language journals in the field of the studies of historical knowledge and practice. A number of the crucial debates on the nature of history and historical knowledge have been hosted in the journal, whose editorial policy is renowned for its pluralism as well as ambition to bring together multiple and diverging perspectives on historical knowledge and practice. Even in the last decade, the journal has published papers from heterogeneous conceptual frameworks, postmodern as well as positivist, critical of Eurocentrism as well as praising progress and universal history. Furthermore, the journal's editors have tried to take into account the developments in French or German philosophy of history, and have occasionally published papers in French or German.

For these reasons, we believe that a content analysis of the journal provides a fruitful opportunity to trace the transformations of the debates on history since it started in the 1960s, and, building on this, to provide an account of the research topics and problems by describing their changing salience.

The object of the content analysis, findings of which we will sum up here, are the abstracts of the papers published in the volumes of History and Theory between 1960 and 2005, amounting to a total of 192 issues, including 45 Beihefte and theme issues. We have coded the papers published by the journal in that period using the following procedure. ${ }^{2}$ First, we categorised the papers according to their key concepts (for example, objectivity, interpretation etc). Then we coded the papers so as to reflect their theoretical framework (for example, positivism, discourse analysis, etc.). Approximately the half of the papers turned out to be historically oriented, i.e. focused on ideas of history that have become elements of the tradition of philosophy of history as an academic discipline. In order to take such papers into account, they were coded according to their focus on an author, school or period (for example Nietzsche, German historicism or classical antiquity).

After the coding, we divided the journal volumes into three periods, the first covering the volumes issued from 1960 to 1974 , the second from 1975 to 1989 , and the third from 1990 to 2005 . We decided to classify the volumes in this way because it articulates the history of the journal into three periods of comparable extent. In drawing the dividing lines between the periods, we also took into account the fact that they came close to the publication dates of two important books, Hayden White's Metahistory (reviewed in the journal in 1974, a year after it was published) and A New Philosophy of History, edited by Frank Ankersmit and Hans Kellner (reviewed in the journal in 1995, the same year it was published).

Then we calculated, first, the frequencies of the key concepts for the three periods, i.e. how many papers were coded according to any of the key concepts that we were able to identify in the earlier 
stages of the analysis. Second, we calculated the frequencies of the papers referring to the theoretical frameworks identified earlier. Third, we calculated the frequencies of papers referring to authors, periods or schools belonging to the tradition of philosophy of history. In view of the fact that the papers often refer to authors only marginally, without treating them as their main topic, we decided to take into account the relative weight of the author references and ascribed half of the normal weight of 1 to any paper discussing at length an author who is not the main topic of that paper.

In the final step of the analysis, we compared the frequencies of the key concepts, theoretical frameworks, author references, period and school references. We believe that this procedure has produced a coherent picture of the development of the studies of historical knowledge and practice as reflected by the editorial policies and the content of History and Theory. In the following paragraphs, we will try to describe that picture from the perspectives of the development of the research topics, of the theoretical frameworks and of the canon of theory of history.

\section{Transformation of research topics}

In the first period, which covers the volumes of the journal issued between 1960 and 1974, the relative weight of the research topics associated with classical philosophy of history is already quite insignificant. The papers dealing with such topics amount to approximately $15 \%$, with half of them focusing on the issues of what is history and what is philosophy of history. The period is however dominated by research topics associated with positivism: if and how is it possible to constitute history as a science, what is the status of historical facts, explanations, laws and causality, is historical knowledge capable of claiming objectivity (the papers discussing such topics constitute about $40 \%$ of the texts published by the journal in the period). The research topics associated with the opposition to positivism crystallising around the concepts of understanding and narrative, and typically inscribed in the framework of analytical philosophy, are relatively marginal (the papers tackling the problems presented by historical understanding and narrative, which would turn out to be insurmountable for positivism, form approximately $16 \%$ of the publications in the period). Analytical philosophy of history is nevertheless quite significantly represented by papers that attempt to ground their projects of studying history on the accomplishments of other academic disciplines - quite often sociology, but also political science, economics and psychology $(29.6 \%$ of the publications in the period).

The distinctive research topics of positivism - objectivity, science, laws or facts of historical knowledge - nearly disappear from the pages of the journal in the second period, covering the volumes issued between 1975 and 1989 (when papers focusing on such topics, including the critiques of positivism, constitute approximately $9.9 \%$ of the publications). The positivist research topics lose their dominant position to a family of issues which have at their core the problem of historical writing - the rhetoric of historiographical texts, the structure of historical narratives, the representation of the past, interpretation in historiography, the impact of the present on historical writing, the institutionalisation of history as an academic discipline (the papers dealing with such topics amount to $43.9 \%$ of the publications in the period). The declining importance of positivism is further confirmed by the fact that the share of papers on characteristically positivist topics published in the Beihefte decreases from $28.5 \%$ in the first period to $10.6 \%$ in the second period, in which they are almost 
twice outweighed by papers dealing with narrative, rhetoric or image (19.1\%). ${ }^{3}$ To put it differently, theory of history, almost completely dominated by positivism until the mid-1960s, is similarly dominated in the 1980s by research topics that will develop into the autonomous research field that became known as the "new philosophy of history" in the beginning of the next period.

Another important trend between 1975 and 1989 is the considerable decrease of the impact of social sciences on philosophy of history (the relative weight of papers based on social science dropped from $16 \%$ of the publications in the first period to $7 \%$ in the second period). Psychology, however, retains in the second period its stable yet minor influence. The period also displays an inclination to solving the problems of philosophy of history by means of concepts drawn from logic and physics, predominantly the logic of possible worlds and chaos theory (yet the relative weight of that kind of discussions is rather insignificant, at $2.8 \%$ of all publications in the period).

The third period, covering the volumes of the journal issued between 1990 and 2005, is dominated by research topics associated with the new philosophy of history, which maintains its hegemony (37\% of the publications focus on historical writing, rhetoric, narrative, interpretation and the impact of the present on the representations of the past). Yet the period is characterised by the emergence of new lines of research dealing with histories deemed to be "other" to the conventional, canonical historical narrative - women's history, colonial and postcolonial history, working-class history, or, if we are to sum up, the histories of the social groups that are not considered to be historical victors in the perspective of the 1990s. But those "other" histories have not been accidentally neglected by modern historiography, and they cannot just be appended to the conventional historical narratives reflecting the perspectives of the historical "victors". The research in such "other" histories therefore assumes that such "other" histories have been excluded from modern historiography because of its conceptual framework and because of the articulation of its objects, so narrating such histories would imply abandoning the concept of universal history and recognising the inherent multiplicity and incommensurability of human histories. ${ }^{4}$ An indication of the impact and the fecundity of this line of research is the fact that although the topic had already emerged in the end of the previous period, i.e. in the second half of the 1980s, the share of the papers dealing with "other" histories goes from $3.5 \%$ of the publications in the second period up to $17.4 \%$ in the third period, reaching the relative weight of the positivist papers before 1960 and 1974, and of the papers on historical writing between 1975 and 1989. Further confirmation of the importance of "other" histories is the prominence enjoyed by papers in the theme issues within the conceptual frameworks of gender, postcolonial and subaltern history, which amount to $18.2 \%$ of the publications, outweighing even the papers dealing with otherwise salient topics such as historical narrative, rhetoric or representation of history (17.3\%), possibly due to the theme issues on history and feminist theory (1992), history making in Africa (1993), and secrecy and lies in history (2000).

Other important lines of research emerging after 1990 are discourse analysis and the studies of national identity. As it is the case with the studies in "other" histories, they are not detached from the problems of the new philosophy of history. The concept of discourse, for example, involves a self-reflexive attitude to the language of philosophy of history, textual analysis and examination of the formation of concepts, similar to the studies in historical writing and rhetoric. And if discourse 
analysis dissociates itself from such studies, this is due to its focus on the nexus between knowledge and power which rhetorical analyses of historiography tend to neglect.

Another important feature of the period is the increasing weight of research topics associated with positivism and gravitating around the problem of objectivity. It would be more appropriate, however, to describe the papers dealing with such topics as neopositivist rather than positivist, since they tend to reformulate the problem in terms of the objectivity of historiographical interpretation, and not as a problem of the objectivity of historical knowledge as it was the case with the positivist discussions of objectivity in the first period, from 1960 to 1974. Furthermore, the question of the objectivity of historiographical interpretation is generally asked in the hope that it would eventually lead to establishment of standards of objectivity that would allow the development of a philosophy of history modelled on the natural sciences; the potential standards of objectivity are generally sought in chaos theory, the logic of possible worlds and counterfactual analysis. And although the relative weight of such arguments has in general increased insignificantly, from 2.8\% between 1975 and 1989 to 3.5\% between 1990 and 2005, due to the editorial policy of the journal that aimed at encouraging and advancing this line of research, they enjoyed significant prominence in the theme issues (10.7\% of all the papers published in theme issues between 1990 and 2005).

The project to develop a viable contemporary theory of progress founded on evolutionary biology derives its impetus from analogous hopes. Its relative weight amounts to $3.9 \%$ of the publications in the period, yet if we take into account its increasing presence in the journal from the early 1990s, the influence it bears on theory of history is significantly stronger than the influence of social sciences or psychology. This influence is particularly felt in the theme issues of the period, in which the share of papers referring to biology, particularly due to the issues on evolutionary ideas and history (1999) and environment and history (2003), amounts to 9.1\%, outweighing even the papers dealing with problems of historical writing (8.3\%).

Between 1990 and 2005, the objectivity of historical interpretation is frequently argued not from the perspectives of physics, biology or the logic of possible worlds, but rather from the perspective of a politically conservative humanism, which derives its motivation from the claim that the values of western civilisation need to be shielded from the alleged relativism of postmodern theory of history. ${ }^{5}$ Another distinguishing feature of the conservative humanism of the period is that it commonly refers to exemplary historical events that cannot be plausibly interpreted along different lines (the foremost example being the Holocaust). The share of papers associated with this strain of conservative humanism amounts to $8.1 \%$ of the publications in the period. It is also worth mentioning that conservative humanism often ends in a call for the reversal of the linguistic turn, supposedly to bring us back to the rational and scientific philosophy of history before postmodernism.

The influence of social sciences on philosophy of history, which diminished in the second period, tends to decrease further after 1990 (this influence is detectable in $7 \%$ of the publications between 1975 and 1989, but in only 2\% of the publications between 1990 and 2005). Moreover, even the relative weight of the papers drawing on psychology, which remained relatively stable in the first two periods, decreases from 4.3\% of the publications between 1975 and 1989 to only $0.8 \%$ after 1990 . 
The period after 1990 also reflects the increasing presence of cultural studies, absent from the pages of the journal before 1990 (3.9\% of the publications between 1990 and 2005).

\section{Transformation of theoretical frameworks}

The transformations of the theoretical frameworks of the papers run parallel to the transformations of their research topics, yet an analysis of them allows one to take into account trends that would have otherwise remained unnoticed. The publications in the first period, covering the volumes of the journal between 1960 and 1974, are, of course, dominated by positivism and social sciences. Of the papers, $47.2 \%$ and $23.9 \%$ fall into these categories, respectively. In the second period, between 1975 and 1989, positivism and social science lose their hegemony to the new philosophy of history, which shapes the theoretical background of $35.9 \%$ of the papers, with only $9 \%$ of the papers associated with positivism and $10.2 \%$ of the papers drawing on social sciences. In all the three periods, studies in theory of history are shaped also by a number of conceptual frameworks that do not have enough relative weight to dominate the field, but which yet enjoy a stable and productive presence - analytic philosophy, speculative philosophy of history and anthropology. The stability of these conceptual frameworks is explicable by the fact that their proponents managed to establish research communities which remained viable despite or perhaps because of their relatively smaller scale. In the late 1960s, phenomenology and hermeneutics also emerged as stable theoretical frameworks embodied in nondominant research communities, as was the case with positivism after its marginalisation in the 1970s.

An interesting phenomenon is the sharp growth of the presence of Marxism in the second period, followed by its almost complete disappearance from the journal after 1990. This phenomenon is explicable, on the one hand, by the Cold War and its subsequent discursive reinterpretation in light of the political and economic developments in the so-called Eastern bloc after 1989. On the other hand, the disappearance of Marxism after 1990 can be explained by the advent of the critical theories which managed to appropriate the critical function of Marxism while detaching it from Marxist politics (the most salient critical theories being postcolonial studies and feminism, which shaped the conceptual frameworks of $11.4 \%$ and 5\%, respectively, of the papers published between 1990 and 2005). ${ }^{6}$ To put it in other words, while in the 1970s Marxism was by and large the dominant theoretical framework oriented at the critique of modern societies and their ideologies, in the 1990s such critiques were more often inscribed within the frameworks of various critical theories that, unlike Marxism, offer the advantage of not being burdened with a model of universal history and claims of objective knowledge of historical laws.

As we have already mentioned in the preceding section, the period from 1990 to 2005 witnessed the increasing presence of neopositivism and conservative humanism, accounting for $10.2 \%$ and $14.2 \%$, respectively, of the publications, as well as the emergence of theoretical frameworks affiliated with the new philosophy of history - discursive analysis, microhistory and identity studies which cover $5.7 \%, 4.3 \%$ and $8.5 \%$, respectively, of the papers published in this period.

\section{Transformation of the canon}

In the first two periods, the relative weight of the papers oriented towards the history of philosophy of history is equal to or even exceeds the weight of the papers focusing on contemporary debates 
or issues. As the journal does not entertain the ambition to offer a systematic history of the discipline, the editorial policy seems to be to publish papers on authors deemed to be of importance to the development of philosophy of history. In view of this, the authors presented on the pages of the journal are representative of its canon of philosophy of history (in the sense of a succession of classical figures who retain their authority notwithstanding their distance in time).

In the analysis of the canon articulated by the journal, we have taken into account the authors that have been the main topic of more than one paper. Single papers on an author have been coded as papers on the relevant school of thought or period (for example, we have categorised the one paper on Ranke as a paper on German historicism). We believe that this approach has the advantage of drawing a line between the authors that are not a matter of occasional interest, while at the same time taking into account even the occasional interest in one or another thinker on history.

The most salient author in the first period, between 1960 and 1974, is Max Weber, followed by Hegel and Marx (of course, the papers of the period are more against Marx rather than on Marx, as in the Cold War context he was ascribed the role of the foremost adversary of philosophy of history). Objects of weaker yet constant interest are the ideas of Karl Hempel, Robert Collingwood, Giambattista Vico, Jean-Paul Sartre, Claude Lévi-Strauss and even Michel Foucault, whose book The Order of Things is presented for the first time at the end of the period (Foucault's work, however, is still viewed as a peculiar version of structuralist history, and therefore associated with the Annales school rather than with poststructuralism).

In the second period, between 1975 and 1989, Hempel, Sartre and Lévi-Strauss lose their canonical status, while the philosophies of history of Hegel and Vico are already the main topics of single papers. At the same time, the papers on Weber, Foucault and Collingwood retain and, to an extent, even increase their relative weight. However, the canon of the journal in the second period is dominated by Marx, now more of an authority than adversary, as well as two figures of new salience - Johann Gustav Droysen and Hayden White.

In the third period, between 1990 and 2005, the relative weight of the papers oriented towards the history of the discipline significantly decreases, possibly because of the widespread opinion that the early 1990s was witnessing the emergence of a new paradigm whose problems and concepts are often quite detached from classical philosophy of history. The key figures of the canon articulated by the journal in the first two periods - Marx, Weber and Collingwood - are now represented by single papers; the significant interest in Droysen, Comte, Michelet or Nietzsche characteristic of the 1980s is on the wane. The authors who retain their canonical status are Foucault and White, the relative weight on the latter increasing to a point that makes him the central figure of the canon. In fact the canon of the last period incorporates only one new author who played a key role in the emergence of the new philosophy of history - Frank Ankersmit.

Of course, this account of the canon articulated by the journal would be incomplete if one does not take into account the papers dealing with schools or periods in philosophy of history. In this respect, the period between 1960 and 1975 is dominated by papers focusing on the distant past of the discipline - the Enlightenment, Renaissance and classical antiquity - which are covered in 50\% 
of the historically oriented papers. Objects of weaker interest are historicism, positivism, classical German philosophy of history and critique of Marxism, which form the topics of 14.6\%, 10.4\%, $8.3 \%$ and $8.3 \%$, respectively, of the historically oriented papers. The interest in classical philosophy of history remains stable in the period between 1975 and 1989, yet the relative weight of papers on the Renaissance, Enlightenment and classical German philosophy of history significantly decreases. The period is marked by a sharply growing interest in Marxism, historicism, poststructuralism and the new philosophy of history as well as by the increasing interest in phenomenology and hermeneutics, which were being raised for the first time in the journal. The period between 1990 and 2005 is dominated by the interest in the new philosophy of history, poststructuralism and postmodernism, which are topics in $41.4 \%$ of the historically oriented papers. The interest in classical and Marxist philosophy of history practically vanishes in this period, and the salience of historicism fades away. In this sense, the pages of the journal between 1990 and 2005 are dominated by papers focusing on the near rather than distant past of the discipline. It is worth noting that after 1990 the relative weight of papers presenting analytical philosophy of history as an element of the history of philosophy of history is quite greater than the relative weight of the papers that refer to analytical philosophy of history as their conceptual framework. It seems that, from the point of view of the historically oriented papers published by the journal after 1990, analytical philosophy of history tends to recede into history of philosophy.

\section{The institutional analysis}

The transformation of the problematics and the conceptual frameworks of philosophy of history reshaped its institutionalisation in the 1990s. Although philosophy of history has emerged as a philosophical discipline, this transformation outlines a broader field of knowledge about history extending beyond the disciplinary boundaries of philosophy.

An indication of the reinstitutionalisation of philosophy of history is the fact that the relevant university courses are increasingly situated not only in faculties of philosophy but also in faculties of history, and even scattered about undergraduate and graduate programmes in sociology, political science, international relations or regional studies.

In order to describe this process of reinstitutionalisation and to explain its driving forces, we decided to analyse the curricula in philosophy of history or on topics relevant to philosophy of history in 22 British, German, United States, French and Russian universities. ${ }^{7}$ As the only accessible sources of information on the university curricula were the websites of the universities, the objects of the analysis were the first 150 philosophy of history curricula returned by a Google Scholar search conducted on 27 January 2006. ${ }^{8}$ The curricula we were able to retrieve had been situated both in highranking universities such as Oxford, Cambridge or Harvard and less renowned academic communities such as the European University at St Petersburg.

The first step of the analysis consisted in classifying the curricula. Taking into account their focal topics, we have been able to identify the following types of university courses regarding philosophy of history as a relevant knowledge: speculative philosophy of history, philosophy of historical development, classical philosophers of history, hermeneutics, historical writing, professional knowledge for historians, and applied philosophy of history. 
The curricula focusing on speculative philosophy of history recapitulate the history of the discipline before the challenges to the legitimacy of historical knowledge posed by positivism and hermeneutics. Undeniably, such courses occasionally include speculative projects from the second half of the twentieth century and often finish with a discussion of Francis Fukuyama's The End of History (1992). Courses on speculative philosophy of history tend also to amalgamate the analysis of classical speculative theories with the ambition to produce grand theories or narratives of their own, or to solve eternal problems such as, for example, what is the goal of history, the ontological status of the past, the common patterns of historical development, whether a metaphysics of history is possible, or what the place of humanity in history is and so on.

The curricula focusing on philosophy of historical development examine Enlightenment and postEnlightenment philosophies of historical progress, interpreting them as theories of development or reorienting them to development-relevant issues such as the purpose, patterns or anthropological constants in history. Such courses generally reformulate the concept of progress so as to adapt it to the current situation, often by making use of biological and physical models, or by developing conceptual schemes which rearticulate the subject of development from humanity to civilisations conceived in the vein of Samuel Huntington (1996).

The curricula centred around classical philosophers of history usually examine the ideas on history of thinkers as Hegel, Kant or Heidegger. They are usually institutionalised as courses in history of philosophy rather than as courses in philosophy of history.

The courses in hermeneutics are also situated in the undergraduate programmes in history of philosophy, yet in view of the fact that such courses discuss the historical nature of understanding in connection with the nature of the understanding of history, they are often recommended to undergraduate students in history and sociology as an introduction to philosophy of history.

The university courses in history writing tend to focus on the new philosophy of history and the problems which have shaped this research field since the 1970s - historical narrative, figurative language in history, representation of the past, the impact of the present on the past, institutionalisation and professionalisation of historical knowledge, or the nexus between knowledge and power. Naturally, the canon of this type of courses is shaped by authors such as White, Ankersmit, Foucault or Paul Ricoeur.

The courses discussing the professional knowledge of historians aim to prepare the students in history for their future work. They introduce students to the so-called auxiliary sciences of history - archives, diplomatics, codicology, paleography, siglliography, qualitative research methods. Yet, the courses of this type discuss methodological problems as well. For example, they introduce students to problematics such as historical writing, the relationships between history, narrative and rhetoric, approaches to historical interpretation, and the responsibility of historians to history. Such courses are often limited to the history of a region or a period, for instance "Writing about Roman History" at the Sorbonne or "Themes and Methods in the History of the United States" at Harvard.

We have classified as applied philosophy of history the curricula that broach some problems relevant to philosophy of history while focusing on other topics. For example, the courses on phi- 
losophy of science, which have a significant relative weight in the curricula of this type, display an interest in philosophy of history limited to classical issues of positivism such as the possibility of covering laws in history, or the problematic nature of history as science. Topics relevant to philosophy of history are occasionally discussed in courses in moral philosophy or philosophy of politics. Such occasional discussions are scattered as well in university programmes in sociology, history of ideas, gender studies or regional studies, for instance Southeast European or East Asian studies.

The second step of the analysis was to take into account the institutionalisation of the types of curricula we have been able to identify. This step has enabled us to make the observations that the courses focusing on speculative philosophy of history, on hermeneutics or on classical philosophers are situated in philosophical departments; the courses in history writing are ambiguously located in both philosophical and historical undergraduate and graduate programmes; the courses offering professional historical knowledge or discussing the methodology of historical research are institutionalised in the departments of history, and the courses in applied philosophy of history are scattered across university programmes in the social sciences or humanities fields.

The final step of the analysis was to take into account the geographic distribution of the curricula. This step has led us to the following observations: The bulk of the courses in hermeneutics are located in German universities, and even the ones institutionalised outside Germany depend on the affiliation of German professors with the department (as it is the case with Columbia University, for example). The courses in history writing and the introductory courses on professional historical research, in effect, tower above the other types of courses in the American, British and French universities, notwithstanding the fact that those universities regularly offer courses on classical philosophers of history and even on hermeneutics. The courses in philosophy of historical development dominate in Russian universities, which in fact do not provide other types of curricula except for courses in speculative philosophy of history. A particular feature of the British situation is the ambition of smaller US-based universities such as Northwestern University or Earlham College to benefit from the conservative policies of the philosophical departments in Oxford or Cambridge, and to attract students by offering graduate programmes in theory of history.

This study of the university curricula in philosophy of history has produced an account of the extensive reinstitutionalisation experienced by the theoretical knowledge on history. This reinstitutionalisation is explicable by the fact that, in consequence of the diminishing influence of speculative philosophy of history and positivism, theory of history has drifted from topics deemed to be of relevance only or at least predominantly to philosophers, as for example the ontological status of the past, the goals and nature of historical knowledge, its objectivity or its specific nature. Since the 1970s, the theoretical research in history had increasingly focused on problems of importance to historians as well as to philosophers, for example historical writing, narrative or interpretation. The institutional localisation of the courses discussing such problems in the late 1990s amply illustrates the dissemination of the objects, concepts and research techniques of philosophy of history scattered across heterogeneous fields such as sociology, political science, regional studies, international relations and cultural studies, among others, a dissemination driven by the growing importance of historical knowledge and praxis to the understanding of the constitution of identity, representation or the conceptual framework of contemporary political theory. 
To sum up the findings of the study, if before the 1970s one could still assume that a course in philosophy of history should be situated in a faculty of philosophy, now we are witnessing quite a different regime of institutionalisation: the problematics of philosophy of history have long since expanded beyond the dividing lines that mark out the territory of philosophical programmes, faculties or departments. To put it differently, the current theoretical research on history, the research on the conditions of possibility of historical knowledge, is increasingly becoming an interdisciplinary research field, in which excellence is more adequately achievable by advanced research centres such as the ones at Columbia University or the University of California, Berkeley.?

\section{Conclusions}

Notwithstanding its invented classical tradition, philosophy of history emerged as an Enlightenment project. Yet the contemporary theory of history is quite dissociated from its Enlightenment roots, on one hand due to the pressing importance of newly emerging problems such as its justification as an academic discipline, and, on the other, due to the rearticulation of the concept of history so as to reflect the importance of historical narratives, their social effects or the difficult nexus of representation, time, identity and writing about the past..$^{10}$

As these transformations are unfinished, the current situation in philosophy of history is difficult to present. Yet we believe that the findings of the content analysis of the volumes of History and Theory between 1960 and 2005, and the analysis of the institutionalisation of university courses in philosophy of history, which we have summarised in this article, invite the conclusion that the principal lines of problematisation along which the discipline has developed in recent decades are rhetoric, language, patterns and modes of historical narrative, discursive, social and political uses of knowledge on history, the historical formation as well as the changing functions and salience of key concepts and narratives. The different lines of problematisation have invited analytical strategies that draw their concepts and techniques from sources as heterogeneous as discourse analysis, phenomenology, rhetoric or cultural studies. Yet the diverging paths seem to outline a common ground - the social representation of history.

As a consequence, after the 1960s philosophy of history has radically changed its perspective on allegedly familiar problems, from developing standards of historical knowledge to acknowledging its variety, historicity, social effect or modes of production, and to studying the uses of history. The principal question philosophers of history now ask is how is history represented rather than what is history. And as this question is relevant to any research that takes into account the historical constitution of its objects, philosophy of history has been disseminated in research areas as different as political science and cultural studies, in consequence being reinstitutionalised as an interdisciplinary field, which in the near future would be perhaps more appropriately defined as historical knowledge studies due to its focus on the conditions of possibility, operation, structure, institutional praxis, critical potential and political relevance of our knowledge about history.

\section{NOTES}

1 This short and inescapably simplified summary of the development of philosophy of history as an academic discipline is based on Peter Novick, That Noble Dream: The "Objectivity" Question and the American Historical Profession (Cambridge: Cambridge UP, 1988), Georg G. Iggers, Historiography in the 
Twentieth Century: From Scientific Objectivity to the Postmodern Challenge (Middletown: Wesleyan UP, 2005), Frank R. Ankersmit, "The Origins of Postmodernist Historiography," in Historiography between Modernism and Postmodernism: Contributions to the Methodology of Historical Research, ed. Jerzy Topolski (Amsterdam: Rodopi, 1994), Robert F. Berkhofer, Jr., Beyond the Great Story: History as Text and Discourse (Cambridge: Belknap Press, 1995), and Beverley C. Southgate, Postmodernism in History: Fear or Freedom? (London: Routledge, 2003).

2 I have devised the procedure following the methodology described in Kimberley Neuendorf, The Content Analysis Guidebook (London: Sage, 2002).

3 The trends exhibited by the contents of the Beihefte and later by the contents of the theme issues are of particular importance, as they reflect more closely the editorial policies of the journal than the regular issues.

4 For an influential account of this argument, see Robert Young, White Mythologies: Writing History and the West (London: Routledge, 1990).

5 Of course, humanism in this sense is little more than a label marking a discursive position in the cultural wars that shook American humanities in the 1980s, a discursive position defined more by its opposition to new historicism, cultural studies, structuralism and poststructuralism, rather than by any significant link to the conservative humanism in the vein of Matthew Arnold, or to the idea of humanism in general. For the genealogy of conservative humanism as a discursive position in the cultural wars of the 1980s, see Catherine Gallagher and Stephen Greenblatt, Practicing New Historicism (Chicago: Chicago University Press, 2001), 1-3, 65-68. For a representative discussion of the basic premises of this particular kind of humanism, see Graham Good, Humanism Betrayed: Theory, Ideology and Culture in the Contemporary University (Montreal: McGill-Queen's University Press, 2001). For representative papers published in History and Theory, see James Fitzgerald, "History in the Curriculum: Debate on Aims and Values," History and Theory 22/4 (1983): 81-100 or Elizabeth Ermarth, "Agency in the Discursive Condition," History and Theory 40/4 (2001): 33-57.

6 For a detailed account of this process of marginalisation of Marxism by cultural studies and critical theory, see Catherine Gallagher, "Marxism and the New Historicism," in The New Historicism, ed. Harold A. Veeser (Minneapolis: Michigan University Press, 1989), 37-48.

7 The objects of study are curricula in philosophy of history accessible on the websites of the following universities: Oxford University; Cambridge University; Earlham College; Northwestern University; Free University of Berlin; University of Konstanz; Leipzig University; University of Freiburg; Heidelberg University; Novosibirsk State University; St Petersburg State University; European University at St Petersburg; Russian State University for the Humanities; Sorbonne University; University of Paris 8; University of California, Berkeley; Yale University; Columbia University; Pennsylvania University; Harvard University; University Chicago; University of California, Los Angeles; Central European University.

8 Of course, as one cannot claim that the curricula retrieved by this method are a representative sample of the courses in philosophy of history, the analysis of their institutionalisation is illustrative rather than representative.

9 For an account of the emergence of such interdisciplinary research networks and their intricate and often tenuous relationship with the disciplinary institutionalisation of knowledge, see for example Monika Fludernik, "Threatening the University: the Liberal Arts and the Economization of Culture," New Literary History 36/1 (2005): 57-70.

10 For a detailed account of this transformation, see Ernst Breisach, On the Future of History: The Postmodernist Challenge and Its Aftermath (Chicago: Chicago University Press, 2007). 